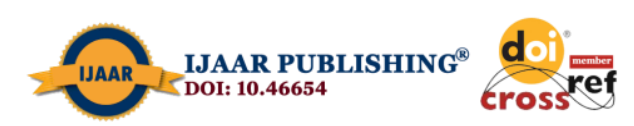

International Journal of Research in Education and Sustainable Development | ISSN: 2782-7666

Journal DOI: www.doi.org/10.46654/IJRESD

Vol. 1, Issue 3 (March, 2021) | www.ijaar.org

Article DOI: www.doi.org/10.46654/IJRESD.1304

\title{
FACTORS THAT LED TO THE DECLINING STANDARD OF PRIMARY EDUCATION IN ADAMAWA STATE, NIGERIA
}

\author{
HAMIDU MOHAMMED JADA ${ }^{1}$, ALI ABDU GIGINYU ${ }^{2}$, MUHAMMAD ALI MUTAH ${ }^{3}$ \\ ${ }^{1 *}$ Federal University Dutse, Jigawa State, Nigeria. 07038417827, hamid.jada@gmail.com \\ ${ }^{2}$ Federal University Dutse, Jigawa State, Nigeria. 08069337226, aliabdullahigiginyu@ yahoo.com \\ ${ }^{3}$ Federal University Dutse, Jigawa State, Nigeria. 08036467811, 9256.mmali@gmail.com
}

Correspondence: Hamidu Mohammed Jada. Faculty of Education, Federal University Dutse Jigawa State, Nigeria.07038417827, hamid.jada@gmail.com

\begin{abstract}
The study assesses the Factors that led to the Declining Standard of Primary Education in Adamawa State, Nigeria. The study involves 1,966 primary schools of Adamawa state and a total of 335 respondents. Percentage, Frequency and mean score statistical tools were used in analyzing the data. The general objectives of the study is to assess the Factors that led to Declining Standard of Primary Education in Adamawa State, Nigeria, below are the specific objectives: To identify the human factors that lead to the declining standard of primary education in Adamawa State, Nigeria. To identify the non- human factors that lead to the declining standard of primary education in Adamawa State, Nigeria and to develop policy and recommendation for the improvement of primary education in Adamawa State, Nigeria. The findings of the study indicated that highest average value 3.70 mean score of the factors led to declining standard of primary education in Adamawa state, Nigeria. The study recommended the following: Recruitment, training and regular teachers workshops, conducive learning environment must be provided by government, teachers salary scheme to be reviewed, adequate teaching materials to be provided, establishing good rapport between teachers and the community. Reviewing the Curriculum Structure and further research should be carried out periodically.
\end{abstract}

KEYWORDS: Declining, Standard, Primary Education 


\section{Background of the Problem}

The primary school which is a major focus of this study in line with the objectives of Universal Basic Education (UBE) of inculcating values, norms and attitude that are accepted in the society, serve as a foundation for subsequent education (Balle, 2010). In a study done in Oyo and Osun states of Nigeria by Sofowora (2010), reveals that the main problems that lead to the declining standard of primary education include: financial problems, incompetent teachers, overcrowded classrooms, and narrow curriculum content, high-rate of drop-outs and lack of quality control. He (Sofowora) further lamented that in the day-to-day administration of the primary schools, heads of schools face myriad administrative problems which militate against the effective running of their schools. These may range from lack of qualified and dedicated teachers, insufficient funding to maintain schools and the roles of the Government towards the growth and development of Primary Education in Adamawa state, paying teachers' salaries, and interference by parents. Others include indiscipline on the part of teachers and pupils and uncooperative attitudes of other school staff. Where the heads fail to arrest these situations, the smooth running of primary schools is compromised (Akande, 2010). In a study done by Lukman and Pwa'usoko (2009) on the students and learning environment revealed that learning cannot be effective without a conducive learning environment. The study also suggested that for teaching and learning to be effective, teaching aids as well as qualified teachers are needed in the Northern Nigerian primary schools. However, the study points out some of the reasons why primary education in Nigeria has declined in its standard such as; inconsistencies in the payment of teacher's salary, lack of conducive learning environment, lack of qualified and committed teachers as well as inadequate teaching materials.

A study done in Bauchi state Nigeria by Tukur and Bukar (2010) on the quality and standard of primary education in the state, also outlined some of the major reasons why primary education has declined in its standard, among which are; lack of qualified teaching personnel, inconsistencies on both the staff and students, shortage of teaching materials and lack of conducive environment for learning (Sofowora, 2010, Gervase \& ItaIwu, 2013, Nuhu, Mashera, Maryam, Agbu \& Ajibili, 2006). A comparative study done on the problems of primary education between the European nations and Japan by Henry and John (2012) revealed that Japan's main primary education problem is, in the knowledge and qualifications of its teachers. While it would be unthinkable in most/all European countries for a primary or secondary school teacher not to have a 4 or 5-year university degree in the field they teach, it is common for Japanese primary or secondary school teachers to teach many subjects, and some completely unrelated to their field of expertise. There are countless Japanese teachers of English who cannot even speak English, and teach mistaken grammar and a katakana pronunciation, (Henry, 2012). Even the Japanese recognize the great deficiencies of their school system, and the need for children to attend private cram schools after school, if they want to learn a bit more efficiently, or just pass university entrance exams. This also explains why Japan is the country with the most private English schools in the world, despite (or justly because of) the gross inability of most of its inhabitants to speak decent English (John, 2011, Henry, 2012). Unlike Singapore, where most people can speak fairly good (or even excellent) English in addition to their mother-tongue (be it a Chinese dialect, Malaysian or Tamil) and India, where even unschooled children speak conversational English, and middle-class to upper-class people usually speak it with a vocabulary and grammar reaching near Native levels (Margie, 2011). While Europe's education problems are mostly in the teacher-students relations, and more a problem of pedagogy, excessive strictness and excess or lack of 
authority, Japan's education problems are mostly about its teachers' competencies and lack of strictness, and the general indifference of both teachers and students toward learning, thus leads to the declining standard of Japanese education. However, a lot of researchers conducted studies on declining standard of primary education in various states of Nigeria and beyond, but there exist no research study on declining standard of primary education in Adamawa state, hence, the focus of this study in line with the above situation, is to investigate into the factors that leads to the declining standards of primary education in Adamawa state, Nigeria, with special emphasis on the human and non-human factors.

\section{Objectives of the Research}

The general objective of the study is to assess the Factors led to the Declining Standard of Primary Education in Adamawa State, Nigeria, below are the specific objectives: To

1. Identify the human factors that lead to the declining standard of primary education in Adamawa State, Nigeria.

2. Identify the non- human factors that lead to the declining standard of primary education in Adamawa State, Nigeria.

3. Develop policy recommendation for improvement of primary education in Adamawa State, Nigeria.

\section{Research Methodology}

The study conducted in Adamawa state, Nigeria,the study area have 21 Local Government Area, with 1,966 public primary schools and 301 private primary schools and 2,600 teachers, the study focuses on public primary schools, sample size of the study were based on the Research Advisor (2006) table, which is 335 respondents were used.Simple Random Samplingwas used, however, after the data have been collected were analyzed and interpreted using the Statistical Package for Social Science (SPSS Version 21) computer software program. Thus, the analysis is done as follows: Pearson $\mathrm{R}$ will be used for the above research questions, mean scores were used to analyse the responses and answer the research question.The research will be significant to government policy makers, head teachers, researchers, and Ministry of Education. The study will be document for factors led to the declining standard of primary education in Adamawa state and in Nigeria in general. 
RESULT AND DISCUSSION

Human factors that lead to declining standard of primary education in Adamawa State

Table 1: Human Factors (school-heads response)

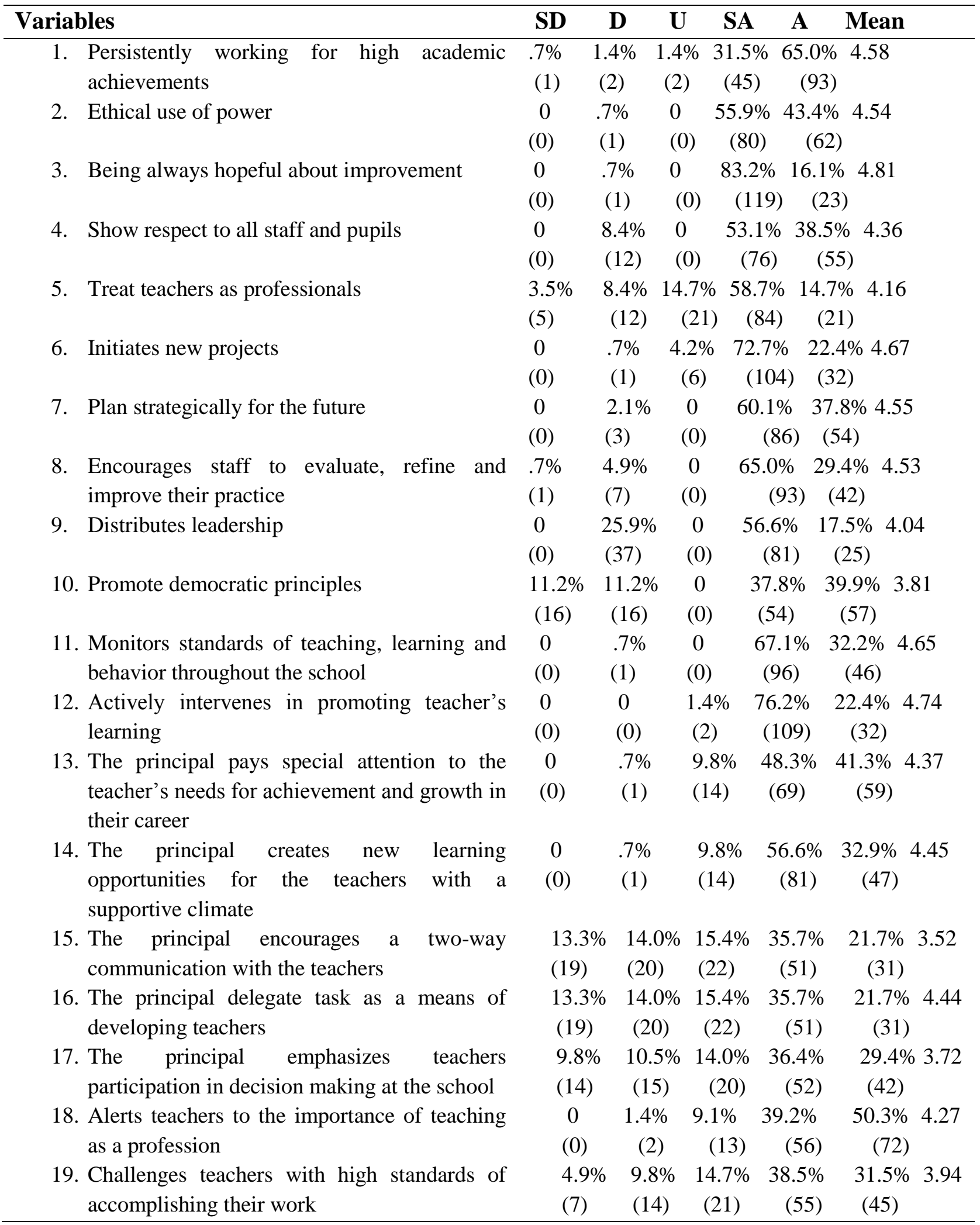


20. Encourages team spirit

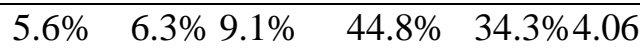
(8)
(9)
(13)
(64)

21. Does not criticize the teachers' mistakes in public

$9.8 \% \quad 18.2 \% 9.8 \% \quad 42.0 \% \quad 20.3 \% 3.66$

$\begin{array}{lllll}(14) \quad(26) \quad(14) \quad(60) \quad \text { (29) } & \text { (14) }\end{array}$

22. Solicits new ideas and creative solutions to $27.3 \% \quad 20.3 \% 18.9 \% 24.5 \% \quad 9.1 \% 2.83$ problems from teachers
(39)
(29)
(27)
(35)

23. Serve as a role model for the teachers to emulate
(0)
(0) (59)
(31)

24. Respected by the teachers

$\begin{array}{llllll}6.3 \% & 8.4 \% & 9.8 \% & 50.3 \% & 25.2 \% & 4.04\end{array}$

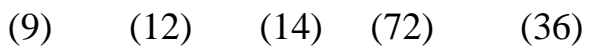

25. Trusted by the teachers

$$
\begin{array}{lllll}
7.7 \% & 14.0 \% & 9.1 \% & 46.2 \% & 23.1 \% 3.86 \\
(11) & (20) & (13) & (66) & (33)
\end{array}
$$

26. Give clear stated expectations for the teachers

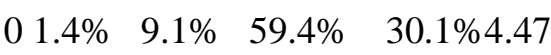
to follow
(0) (2)
(13)
(85)

27. Encourages teachers to try new approaches in their work

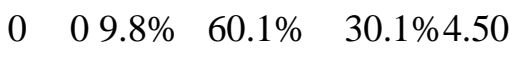

(0) (0) (14) (86)

28. Get teachers to look at problems from many different angels

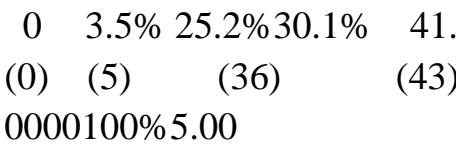

29. Pupils copy notes from the board in class
(0) $\quad(0)$
(0)
(0)
(143)

30. Pupils work in pairs

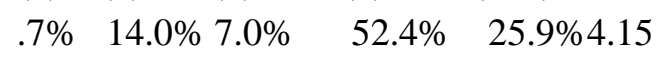
(1) (20)
(10)
(75)

(37)

31. Create a positive learning environment in your school

$07.7 \% 092.3 \% 04.76$

2. Pupils homework are checked in the class

$\begin{array}{llll}\text { (0) } \quad(11) \quad(0) \quad(132) \quad(0) & 0\end{array}$

$00.7 \% 99.3 \% \quad 04.98$
(0) (0)
(1) (142)
(0)

33. Pupils are given chance to ask questions

$\begin{array}{lll}0 & 0099.3 \% & .7 \% 4.99\end{array}$

(0) $\quad(0) \quad(0) \quad(142)$

34. Homework's are corrected in class

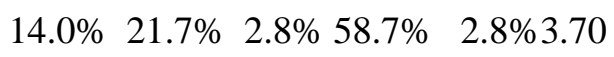

35. Pupils work in groups in class
(20)
(31)
(4)
(84)
(4)

$10.5 \% \quad 18.9 \% \quad 063.6 \% \quad 7.0 \% 3.94$
(15)
(27)
(0) (91)
$\begin{array}{lll}0.7 \% & 099.3 \% & 04.97\end{array}$
(0)
(1)
(0) (142)
(0)

37. Pupils are given chance to ask each other question

$\begin{array}{lllll}23.1 \% & 30.8 \% & .7 \% & 27.3 \% & 18.2 \% 2.95\end{array}$
(33)
(44)
(1)
(39)

(26)

38. Teachers read aloud for pupils to repeat

$00099.3 \% \quad .7 \% 4.99$
(0) (0)
(0)
(142)

39. Video / DVD or audiotapes / CDs are used in class

$\begin{array}{llllll}99.3 \% & 0 & 0 & .7 \% & 0 & 1.02\end{array}$
(142)
(0)
(0)
(1) (0)

40. Play is used to facilitate pupil learning

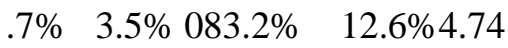
(1)
(5)
(0) (119)
(18)
$99.3 \% \quad .7 \% \quad 0001.00$
$\begin{array}{llll}(142) \quad(1) \quad(0) \quad(0) & 0\end{array}$

41. Computer facilities are used in teaching

$\begin{array}{lllll}00 & .7 \% & 99.3 \% & 0 & 4.98\end{array}$

42. Pupils are taught as a whole class

(0)

(0)

(1) (142)

(0) 
43. So many teachers in your school encourages

$\begin{array}{llllll}24.5 \% & 11.9 \% & 0 & 62.9 \% & .7 \% & 3.65 \\ (35) & (17) & (0) & (90) & (1) & \\ 3.5 \% & 0 & 0 & 88.1 \% & 8.4 \% & 4.77 \\ (5) & (0) & (0) & (126) & (12) & \end{array}$

44. So many students in your school try hard to do

$\begin{array}{llllll}39.95 \% & 30.1 \% & 0 & 28.0 \% & 2.1 \% & 2.48\end{array}$ better school work than their classmates

$\begin{array}{lllll}(57) \quad(43) & \text { (0) } & \text { (40) } & \text { (3) }\end{array}$

45. So many of the students in your school are

$\begin{array}{llllll}16.1 \% & 25.2 \% & 0 & 38.5 \% & 20.3 \% & 3.39\end{array}$ capable of getting A+ and A's in their exams

(36)

(0) (55)

46. So many teachers are encouraging students

$0 \quad 0$

$.7 \% \quad 99.3 \% \quad 0$

4.98

who do not have efficient resources to further

(0) (0)

(1) (142) (0) their education

47. I am committed towards the intellectual development of the students

$100 \%$

(143)

0

$\begin{array}{lll}0 & 0 & 0\end{array}$

(0)

48. I am not willing to help students learn regardless of academic difficulties

$0 \quad 0$

(0)

$\begin{array}{lllll}(0) & (0) & (0) & (0) & (143)\end{array}$

$\begin{array}{lllll}(0) & (0) & (0) & (0) & (143)\end{array}$

(0)

$(0)$
$100 \%$

1.00

49. I can perform in my career if the school board

(1)

0

0

$81.1 \%$

$18.2 \%$

5.00

is sympathetic when I have problems with uncontrollable student

50. I am dedicated to making a difference for

(1) (0) (116)

(26)

4.79

$\begin{array}{lrrlll}3.5 \% & 16.1 \% & .7 \% & 59.4 \% & 20.3 \% & 4.16 \\ (5) & (23) & (1) & (85) & (29) & \end{array}$
school

51. I am willing to develop personal time with students

$3.5 \%$

$3.5 \% \quad 16.1 \% \quad 54.5 \%$

$22.4 \% \quad 4.20$

$\begin{array}{llllll}(5) & (5) \quad(23) \quad \text { (78) } \quad \text { (32) }\end{array}$

52. I am able to influence how well students learn

$8.4 \% 2.8 \%$

$16.1 \% \quad 67.1 \%$

53. I am able to manage difficult and unmotivated

(12)

(4)

(23) (96)

(8) students to learn

54. If there is any discipline problem in school (student), did your administration provide teachers with the and help that they need

$\begin{array}{lllllll}0 & 0 & 15.4 \% & 66.4 \% & 18.2 \% & 4.51 \\ (0) & (0) & (22) & (95) & (26) & \\ .7 \% & 0 & 0 & 99.3 \% & 0 & 4.97 \\ (1) & (0) & (0) & (142) & (0) & \\ 12.6 \% & 33.6 \% & 3.5 \% & 29.4 \% & 21.0 \% & 3.20 \\ (18) & (48) & (5) & (42) & (30) & \\ 37.1 \% & 33.6 \% & 1.4 \% & 21.7 \% & 6.3 \% & 2.41 \\ (53) & (48) & (2) & (31) & (9) & \end{array}$

55. Most discipline problems (students) are handled at the classroom

56. The discipline policy (student) in your school is clearly stated and consistently enforced

57. I am able to perform in my career as I always get the school board support in the area of student's discipline.

58. Indiscipline in schools can lead to the falling standard of education

\begin{tabular}{llllll}
0 & 0 & 0 & 0 & $100 \%$ & 5.00 \\
$(0)$ & $(0)$ & $(0)$ & $(0)$ & $(143)$ & \\
$2.1 \%$ & $1.4 \%$ & 0 & $88.1 \%$ & $8.4 \%$ & 4.79 \\
$(3)$ & $(2)$ & $(0)$ & $(126)$ & $(12)$ & \\
$.7 \%$ & 0 & 0 & $86.7 \%$ & $12.6 \%$ & 4.84 \\
$(1)$ & $(0)$ & $(0)$ & $(124)$ & $(18)$ & \\
$.7 \%$ & $15.4 \%$ & $8.4 \%$ & $44.1 \%$ & $31.5 \%$ & 4.02 \\
$(1)$ & $(22)$ & $(12)$ & $(63)$ & $(45)$ & \\
0 & 0 & $9.8 \%$ & $81.8 \%$ & $8.4 \%$ & 4.72 \\
$(0)$ & $(0)$ & $(14)$ & $(117)$ & $(12)$ & \\
\hline
\end{tabular}


63. Create a collaborative learning organization with the community

(0) (0) (30)

$66.4 \%$

$12.6 \% \quad 4.45$

64. Builds trust within the local community

$0 \quad 0 \quad 0$

(95)

(18)

(0) $\quad(0)$

(0)

$88.1 \%$

$11.9 \% \quad 4.88$

65. Have good relations with the school

$\begin{array}{llll}42.0 \% & 23.1 \% & 13.3 \% & 10.5 \%\end{array}$ board/parents

(33) (19)

(15)

$11.2 \%$

2.25

66. Make the community to be proud of the school

$2.8 \% \quad 0$

$86.7 \%$

(16)

67. Many parents request for feedback from the

$\begin{array}{llll}9.1 \% & 11.9 \% & 6.3 \%\end{array}$

(124)

$10.5 \% \quad 4.81$ principal and teachers as how their children are doing in school

68. Can you recognize student's parents on sight

(17)

(9)

$62.9 \%$

$\begin{array}{lllll}15.4 \% & 31.5 \% & 6.3 \% & 39.2 \% & 7.7 \%\end{array}$

$(45)$

(9)

(56)

$\begin{array}{llll}5.6 \% & .7 \% & 85.3 \% & 8.4 \%\end{array}$

4.73 children earn

(0) (8)

(1) (122)

(12)

70. Many parents are involved in school activities

$81.8 \% \quad 14.0 \%$

$.7 \%$

$3.5 \%$ (fund raising, PTA)

(117)

(20)

(0)

(1)

(5)

71. Many parents provides a conducive learning environment for their children at home

$86.0 \% \quad 4.9 \%$

0

$.7 \%$

$8.4 \% \quad 1.32$

(123) (7) (0) (1)

(12)

\section{Average Mean $=3.97$}

SD = Strongly Disagree, $\mathrm{D}=$ Disagree, $\mathrm{U}=$ Undecided, $\mathrm{SA}=$ Strongly Agree, $\mathrm{A}=$ Agree

The above table clearly shows the responses of the respondents have highly significant mean value to the falling standard of primary education in Adamawa state with the highest mean of 3.97 .

Table 2: Human factors (teacher's response)

\begin{tabular}{clllllll}
\hline Variables & SD & D & U & SA & \multicolumn{1}{c}{ A } & Mean \\
\hline 1. Working for high academic & $6.3 \%$ & $12.0 \%$ & $14.1 \%$ & $41.7 \%$ & $26.0 \%$ & 3.84 \\
achievements & $(12)$ & $(23)$ & $(27)$ & $(80)$ & $(50)$ & \\
2. Ethical use of power & $6.3 \%$ & $12.0 \%$ & $14.6 \%$ & $39.1 \%$ & $28.1 \%$ & 3.81 \\
& & $(12)$ & $(23)$ & $(28)$ & $(75)$ & $(54)$ & \\
3. Hopeful about improvement & $8.3 \%$ & $12.5 \%$ & $14.1 \%$ & $39.1 \%$ & $26.0 \%$ & 3.75 \\
& $(16)$ & $(24)$ & $(27)$ & $(75)$ & $(50)$ & \\
4. Respect to staff and pupils & $6.3 \%$ & $13.5 \%$ & $14.1 \%$ & $39.1 \%$ & $27.1 \%$ & 3.79 \\
& $(12)$ & $(26)$ & $(27)$ & $(75)$ & $(52)$ & \\
5. Treat teachers as professionals & $6.3 \%$ & $14.6 \%$ & $14.1 \%$ & $39.1 \%$ & $26.0 \%$ & 3.77 \\
6. Promote democratic principles & $(12)$ & $(28)$ & $(27)$ & $(75)$ & $(50)$ & \\
7. Monitors standards of teaching, & $8.3 \%$ & $14.1 \%$ & $14.1 \%$ & $39.1 \%$ & $26.6 \%$ & 3.78 \\
learning and behavior throughout & $(16)$ & $(24)$ & $(27)$ & $(75)$ & $(50)$ & \\
the school & & & & & & \\
8. Actively intervenes in promoting & $6.8 \%$ & $13.0 \%$ & $14.1 \%$ & $39.1 \%$ & $27.1 \%$ & 3.78 \\
\hline
\end{tabular}


teacher's learning

9. Plan strategically for the future

10. Promote democratic principles

11. Can perform better if given authority and discretion

12. I feel that as my teaching services grows, my commitment to the school increases

13. The principal pays special attention to the teacher's needs for achievement and growth in their career

14. The principal creates new learning opportunities for the teachers with a supportive climate

15. The principal encourages a twoway communication with the teachers

16. The principal delegate task as a means of developing teachers

17. The principal emphasizes teachers participation in decision making at the school

18. Alerts teachers to the importance of teaching as a profession

19. Challenges teachers with high standards of accomplishing their work

20. Encourages team spirit

21. Does not criticize the teachers' mistakes in public

22. Solicits new ideas and creative solutions to problems from teachers

23. Serve as a role model for the teachers to emulate

24. Respected by the teachers

25. Trusted by the teachers

\section{$\begin{array}{lllll}(13) & (25) & (27) & (75) & \text { (52) }\end{array}$}

$\begin{array}{llllll}6.3 \% & 14.6 \% & 14.1 \% & 39.1 \% & 26.0 \% & 3.77\end{array}$

$\begin{array}{lllll}(12) & (28) & (27) & (75) & (50)\end{array}$

$\begin{array}{llllll}6.3 \% & 12.5 \% & 14.1 \% & 28.1 \% & 39.1 \% & 3.81\end{array}$

$\begin{array}{lllll}(12) & (24) & (27) & \text { (75) } & \text { (54) }\end{array}$

$\begin{array}{llllll}8.9 \% & 12.0 \% & 14.1 \% & 39.1 \% & 26.0 \% & 3.74\end{array}$

$\begin{array}{lllll}(17) \quad(23) & (27) \quad(75) \quad(50)\end{array}$

$\begin{array}{llllll}8.9 \% & 12.0 \% & 14.1 \% & 39.1 \% & 26.0 \% & 3.74\end{array}$

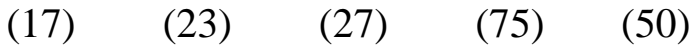

$\begin{array}{llllll}53.1 \% & 24.5 \% & 4.7 \% & 8.3 \% & 9.4 \% & 1.95\end{array}$

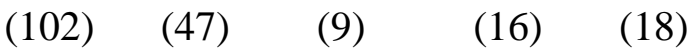

$\begin{array}{llllll}56.3 \% & 21.9 \% & 4.7 \% & 8.9 \% & 8.3 \% & 1.91\end{array}$

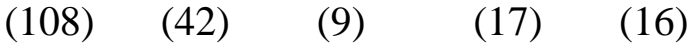

$\begin{array}{llllll}50.5 \% & 22.9 \% & 4.7 \% & 14.1 \% & 7.8 \% & 2.11\end{array}$

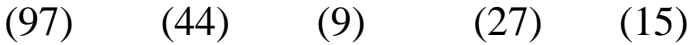

$\begin{array}{llllll}50.0 \% & 29.2 \% & 4.7 \% & 8.3 \% & 7.8 \% & 1.95\end{array}$

$\begin{array}{llll}(96) & (56) \quad(9) \quad(16) \quad \text { (15) }\end{array}$

$\begin{array}{llllll}52.6 \% & 22.9 \% & 7.3 \% & 8.3 \% & 8.9 \% & 1.97\end{array}$

(101) (44) (14) (16) (17)

$\begin{array}{llllll}53.1 \% & 22.9 \% & 4.7 \% & 8.3 \% & 10.9 \% & 1.98\end{array}$ $(101) \quad(44) \quad(9) \quad(16) \quad(21)$

$\begin{array}{llllll}56.8 \% & 20.8 \% & 4.7 \% & 9.9 \% & 7.8 \% & 1.93\end{array}$

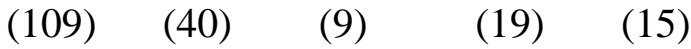

$\begin{array}{llllll}53.6 \% & 24.0 \% & 4.7 \% & 8.3 \% & 9.4 \% & 1.94\end{array}$

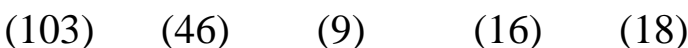

$\begin{array}{llllll}54.2 \% & 21.9 \% & 4.7 \% & 8.3 \% & 10.9 \% & 1.97\end{array}$

$(104) \quad(42) \quad(9) \quad(16) \quad(21)$

$\begin{array}{llllll}53.6 \% & 21.9 \% & 4.7 \% & 8.3 \% & 11.5 \% & 1.98\end{array}$

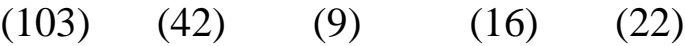

$\begin{array}{llllll}54.2 \% & 22.4 \% & 4.7 \% & 8.3 \% & 10.4 \% & 1.96\end{array}$

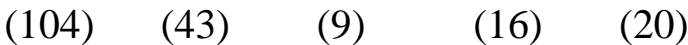

$\begin{array}{llllll}53.1 \% & 24.5 \% & 4.7 \% & 8.3 \% & 9.4 \% & 1.95\end{array}$

$\begin{array}{lllll}(102) & (47) \quad(9) \quad(16) \quad(18)\end{array}$

$\begin{array}{llllll}53.6 \% & 22.4 \% & 4.7 \% & 8.3 \% & 10.9 \% & 1.97\end{array}$




\section{$\begin{array}{lllll}(103) & (43) & (9) & (16) & (21)\end{array}$}

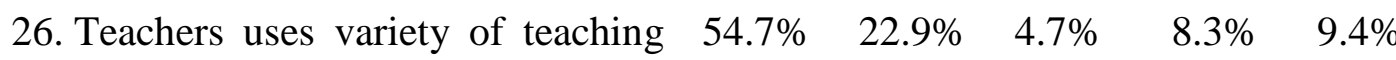
strategies and learning activities to (105) (44) (9) (16) (18) help their students learn

27. The principal does a very good job

$\begin{array}{llllll}53.1 \% & 23.4 \% & 4.7 \% & 8.3 \% & 10.4 \% & 1.97\end{array}$
in getting resources for the school

(16)

28. Encourages teachers to try new approaches in their work

$54.7 \% \quad 22.9 \% \quad 4.7 \%$

$8.3 \% \quad 9.4 \%$

(105)

(44)

(16)

29. Get teachers to look at problems from many different angels.

$53.1 \% \quad 22.9 \% \quad 4.7 \%$

$8.3 \%$

30. Make pupils copy notes from the

(44)

(9)

(16) (21) board in class

(4)

$.5 \% \quad 0$

$97.4 \% \quad 0$

31. Make pupils work in pairs

$18.2 \% \quad 22.9 \% \quad 0$

$(187) \quad(0)$

(35) (44) (0)

$58.9 \% \quad 0$

32. Create a positive learning $3.1 \%$

$2.1 \% \quad 0$

(113) (0) environment in your school

(6)

(4) (0)

$94.8 \% \quad 0$

33. Check pupils homework in the $2.1 \%$

$1.6 \% \quad 0$

(182) (0) class

(3)

(0)

$94.8 \% \quad 1.6 \%$

34. Give chance for pupils to ask you

$4.7 \%$

$.5 \% \quad 0$

(182) questions

(1)

(0)

$94.8 \% \quad 0$

35. Take homework for correction in 0 class

(182)

(0)

36. Make pupils work in groups in

(0)

(0)

0

$100 \%$

5.00 class

$1.0 \% \quad 0$

(0)

(192)

37. Ask pupils questions in class

(2) (0)

$94.8 \% \quad 2.1 \%$

4.86

(182) (4)

$3.1 \% \quad 2.1 \% \quad 0 \quad 94.8 \% \quad 0$

(6)

(4) (0)

$(182)$

38. Give chance for pupils to ask each

$3.6 \%$

$6.3 \% \quad 0$

$87.5 \% \quad 2.6 \%$

4.64 other question

39. Read aloud for pupils to repeat

$0 \quad 0 \quad 0$

(168) (5)

$\begin{array}{llll}(0) & (0) & (0) & (0)\end{array}$

40. Use video / DVD or audiotapes /

$58.9 \%$

$41.1 \% \quad 0$

CDs in class

(79)

(0)

0

$100 \%$

5.00

41. Use play to facilitate pupil learning

$2.1 \% \quad 2.6 \% \quad 0$

(0)

(192)0 1.41

\section{(4)}

(5)

(0)

$94.8 \% \quad .5 \%$

4.83

42. Use computer facilities in teaching

\section{$58.9 \%$}

$38.5 \%$

0

(182)

\section{(113)}

(74)

(0)

$2.6 \% \quad 0$

1.48

43. Teach pupils as a whole class

$4.7 \%$

$.5 \%$

0

(5)

(0)

44. So many teachers in your school

(1)

(0)

$94.8 \% \quad 0$

encourages students to seek extra

$1.6 \% \quad 0$

$(182)$

$(0)$

schoolwork so that they can get

(0)

(3)

(0)

$89.6 \% \quad 8.9 \%$

4.86 better grades

45. So many students in your school

$15.6 \%$

$7.3 \% \quad 0$

$77.1 \% \quad 0$

4.15 
try hard to do better school work

(30)

(14)

(0)

(148)

(0)

than their classmates

46. So many of the students in your

$23.4 \%$

$2.1 \% \quad 0$

$74.5 \% \quad 0$

4.00

class are capable of getting $\mathrm{A}+$ and

(45)

(4)

(0)

(143)

(0)

A's in their exams

47. So many teachers are encouraging students who do not have efficient

$2.1 \%$

(4)

resources to further their education

48. I am committed towards the intellectual development of the students

49. I am not willing to help students learn regardless of academic difficulties

50. I can perform in my teaching career if the principal is sympathetic when I have problems with uncontrollable student

51. I am dedicated to making a difference for students culturally and ideologically in the school

52. I am willing to develop personal time with students outside the classroom

53. I am able to influence how well students learn

$1.6 \%$

(3)

$9.9 \%$

(19)

$1.0 \% \quad 1.6 \% \quad 0$

$1.0 \% \quad 0$

(2)

(0)

$97.4 \% \quad 0$

(3)

(2)

(3)

(0)

$97.4 \% \quad 0$

(187) (0)

54. I am able to manage difficult and unmotivated students to learn

$2.1 \%$

(4)

(0)

$97.4 \% \quad 0$

55. I am able to affect student's academic performance

\section{(3)}

$1.0 \%$

(2)

(0)

$2.1 \%$

(4)

(0)

$10.4 \% \quad 0$

56. I am able to control the enforcement of students' actions

57. I am able to make my students learn better over a period of time

58. My subject matter competence helps to improve students' learning

59. If there is any discipline problem in school (student), did your administrators provide you with the support and help that you may need

60. Most discipline problems

$1.6 \% \quad 1.0 \% \quad 0$

$2.1 \%$ (4) $.5 \%$

\author{
(1)
}

$30.2 \%$

\section{(2)}

$.5 \%$

(1)

$2.1 \% \quad 0$

(4) (0)

(0)

$1.0 \% \quad 0$

(2)

(0)
(187)

$97.4 \% \quad 0$

(187) (0)

$88.0 \% \quad 0$

(169) (0)

$88.0 \% \quad 0$

(169) (0)

$97.4 \% \quad 0$

(187) (0)

$97.4 \% \quad 0$

(187) (0)

$97.4 \% \quad 0$

(187) (0)

$67.7 \% \quad 1.0 \%$ 
(students) are handled at the (5)

(0)

(0)

(187)

(0)

classroom level

61. The discipline policy (student) in

$29.7 \% \quad 20.3 \% \quad 0$

$48.4 \% \quad 1.6 \%$

3.18

your school is clearly stated and

(57)

(39)

(0)

(93)

(3)

consistently enforced

62. I am able to perform in my $9.9 \%$

$2.1 \% \quad 0 \quad 88.0 \% \quad 0$
teaching career as I always get the principal's support in the area of

(0)

(169) student's discipline.

63. Indiscipline in schools can lead to the falling standard of education

0

0

0

$100 \%$

5.00

64. Promote the prevailing values of

(0) (0)

(0) the community in your school

$2.6 \% \quad 0$

$97.4 \% \quad 0$

65. Create and maintain an orderly, 0

(187) (0) purposeful learning environment

(0)

$2.1 \% \quad 0$

$97.4 \% \quad 0$

66. Create a collaborative learning $2.6 \%$

(4)

(0)

(187) (0) organization with the community

$.5 \%$

0

$97.4 \% \quad 0$

67. Builds trust within the local

(0)

(187) (0) community

$1.6 \%$

(1)

0

$97.4 \% \quad 0$

68. Have good relations with the school board/parents

$1.0 \%$

(0)

(187) (0)

69. Make the community to be proud

$2.5 \%$

(2)

$97.4 \% \quad 0$ of the school

0

(0)

(187) (0)

$97.4 \% \quad 0$

70. Work with parents to support students learning

$1.0 \%$

(0)

(0)

(187) (0)

(2)

$1.6 \% \quad 0$

$97.4 \% \quad 0$

71. Encourages a two-way $.5 \%$

(3) (0)

(187) (0) communication with the (1)

$2.1 \% \quad 0$

$97.4 \% \quad 0$ community

(4) (0)

(187) (0)

72. Can you recognize student's 0 parents on sight

$1.0 \% \quad 0$

$97.4 \% \quad 0$

73. Many parents cares about what $.5 \%$

(2) (0)

(187) (0) grades their children earn

74. Many parents are involved in 0

(187) (0) school activities (fund raising, (0)

$1.6 \% \quad 0$

$97.4 \% \quad 0$ PTA)

(3) (0)

(187) (0)

75. Many parents provides a 0

$1.0 \% \quad 0$

$97.4 \% \quad 0$ conducive learning environment (0)

(2) (0)

(187) for their children at home

\section{Average mean $=3.84$}

SD = Strongly Agree, D = Disagree, U = Undecided, SA = Strongly Agree, A = Agree

The table above shows the variable with the highest average mean value 3.84 shows less significant mean value 3.84 . 
The non-human factors that lead to the declining standard of primary education in Adamawa state?

Table 3 below shows the variables that constitute Non-human factors that lead to the declining standard of primary education in Adamawa state as a whole in this study. The total of 16 variables are shown in the table below coupled with the responses of the respondents.

Table 3: Non-human factors (school-heads response)

Variables
1. Find and allocate resources to pursue
important school goals
2. Analyze budgets and reallocate resources
to achieve critical objectives
3. Ensure proper supervision towards
spending the resources
4. Get resources for the school
5. Providing more teaching facilities to aid
learning
6. Primary schools are underfunded by the
government
7. Provide new teaching material/facilities

8. Emphasis in using the teaching SD

D

$\begin{array}{llllll}16.1 \% & 54.4 \% & 8.4 \% & 4.9 \% & 16.1 \% & 2.39\end{array}$

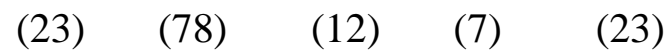

$\begin{array}{llllll}0 & 20.3 \% & 9.1 \% & 66.4 \% & 4.2 \% & 4.16\end{array}$

$\begin{array}{lllll}(0) & \text { (29) (13) (95) (6) }\end{array}$

$28.0 \% \quad 14.0 \% \quad 0 \quad 32.2 \% \quad 25.9 \% \quad 3.20$

$\begin{array}{lllll}(40) & (20) & (0) & (46) & (37)\end{array}$

$\begin{array}{llllll}30.8 \% & 32.2 \% & 7.0 \% & 13.3 \% & 16.8 \% & 2.49\end{array}$

$\begin{array}{lllll}(44) \quad(46) \quad(10) \quad(19) \quad \text { (24) } & \text { (19) }\end{array}$

$\begin{array}{llllll}18.9 \% & 25.9 \% & 23.1 \% & 16.1 \% & 16.1 \% & 2.84\end{array}$

$\begin{array}{lllll}(27) & (37) & \text { (33) } & \text { (23) } & \text { (23) }\end{array}$

$\begin{array}{llllll}59.4 \% & 3.5 \% & .7 \% & 36.4 \% & 0 & 2.50\end{array}$

$\begin{array}{lllll}(85) & \text { (5) } & \text { (1) } & \text { (52) }\end{array}$

$\begin{array}{llllll}22.4 \% & 39.2 \% & 10.5 \% & .7 \% & 27.3 \% & 2.44\end{array}$ materials/facilities to facilitate learning

9. Manage facilities and their maintenance

10. Some pupils sit on a bear floor due to lack of adequate school facilities

11. Engage staff in a decision making process about school curriculum and policies

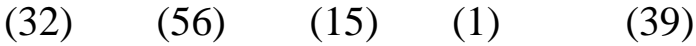

$\begin{array}{llllll}0 & 2.1 \% & 0 & 90.2 \% & 7.7 \% & 4.86\end{array}$

$\begin{array}{lllll}(0) & (3) \quad(0) \quad(129) \quad \text { (11) }\end{array}$

$\begin{array}{llllll}39.2 \% & 42.7 \% & 2.1 \% & 2.1 \% & 14.0 \% & 1.97\end{array}$

$\begin{array}{lllll}(56) & \text { (61) (3) (3) } \quad \text { (20) }\end{array}$

$\begin{array}{llllll}54.5 \% & 7.7 \% & 0 & 36.4 \% & 1.4 \% & 2.57\end{array}$

$\begin{array}{lllll}(78) & (11) & (0) & (52) & \text { (2) }\end{array}$

12. Evaluate curriculum materials for their usefulness in supporting learning

$\begin{array}{llllll}5.6 \% & 41.3 \% & 0 & 35.0 \% & 18.2 \% & 3.35\end{array}$

$\begin{array}{lllll}(8) & (59) & (0) & (50) & \text { (26) }\end{array}$

13. Enough time should be allocated for an effective study of the curriculum by new and old teachers

14. There should be regular evaluation of the curriculum implementation by supervisors and teachers

15. The curriculum used in primary schools are often outdated

$\begin{array}{llllll}2.1 \% & 39.9 \% & 9.8 \% & 23.1 \% & 25.2 \% & 3.27\end{array}$

$\begin{array}{lllll}(3) & \text { (57) (14) (33) } \quad \text { (36) }\end{array}$

$\begin{array}{llllll}8.4 \% & 14.0 \% & 10.5 \% & 58.7 \% & 8.4 \% & 3.95\end{array}$

(12) (20) (15) (84) (12)

$\begin{array}{llllll}.7 \% & 10.5 \% & 10.5 \% & 58.0 \% & 20.3 \% & 4.24\end{array}$

$\begin{array}{llll}(1) & \text { (15) (15) (83) (29) }\end{array}$

16. The school community through PTA should be involved in curriculum supervision

$\begin{array}{lcccll}7 \% & 0 & 0 & 99.3 \% & 0 & 4.97 \\ (1) & (0) & (0) & (142) & (0) & \\ .7 \% & 0 & 0 & 89.5 \% & 9.8 \% & 4.87 \\ (1) & (0) & (0) & (128) & (14) & \end{array}$


The 16 variables shown in the table above are the non-human factors that lead to the declining standard of primary education in Adamawa state, and the variable with the highest mean value 3.37 .

Table 4: Non-human factors (teacher's response)

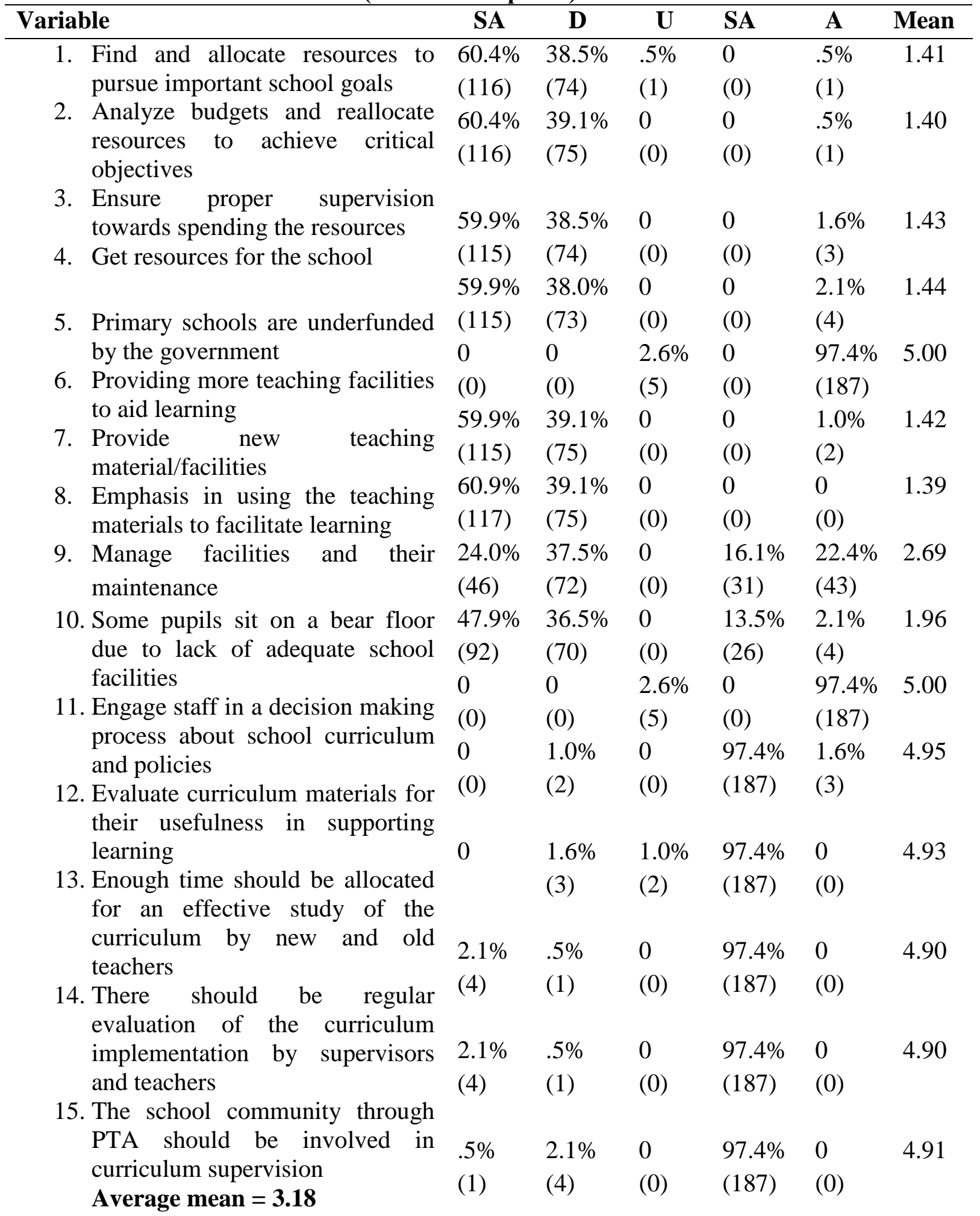

SD = Strongly Agree, $\mathrm{D}=$ Disagree, $\mathrm{U}=$ Undecided, $\mathrm{SA}=$ Strongly Agree, $\mathrm{A}=$ Agree 
The above table shows the Non-human factors that lead to the declining standard of primary education in Adamawa state, Nigeria. The variables with the highest mean value among the 15 variables in the table are; "primary schools are underfunded by the government" and "some pupils sit on a bear floor due to lack of adequate school facilities"' with the mean values of 5.00, which indicates that these two variables leads to the declining standard of primary education in Adamawa state.

\section{Conclusion and Recommendations of the study}

This study assessed the Factors led to the Declining Standard of Primary Education in Adamawa State, Nigeria. Human factors: School-heads responseclearly shows the responses of the respondents have highly significant mean value to the falling standard of primary education in Adamawa state with the highest mean of 3.97, teacher's responseabove shows the variable with the highest average mean value 3.84 shows less significant mean value 3.84 . Non-Human factors: school-heads responseshown in the table above are the Non-human factors that lead to the declining standard of primary education in Adamawa state, and the variable with the highest mean value 3.37 , teacher's responsewith the highest mean value of 3.18, which show highest, affect that to the declining standard of primary education in Adamawa state. Generally, the findings of the study indicated that highest average value 3.70 mean score of the factors led to declining standard of primary education in Adamawa state, Nigeria. The following policy recommendations for improvement of primary education standard in Adamawa state, Nigeria arederived from this study have been made: 1 . Recruitment, training and regular teachers workshops, 2. conducive learning environment must beprovided by government, 3. teachers salary scheme must be reviewed, 4. adequate enough teaching materials and 5. Establish rapport between teachers and community. The study also recommended for further research. 


\section{References}

Adams, P.T (2006). Students and Teachers Factor in the Teaching of Mathematics International Journal of Contemporary Issues in Science, 3(1\&2) 55 - 69.

Adeogu, A.O. (2008). An Investigation into the Maintenance of School Facilities in Ekiti State, Nigeria. Nigerian Journal of Educational Administration and Planning, 8 (1), pp 11-20.

Adesina, A.E (2011). Perceived impact of primary education on the attainment of Nigeria Vision 2020. Mediterranean Journal of Social Sciences, 2(5):6 1 -69.

Adeyemi, T.O and Adu E.T (2010).Enrolment Analysis and the Availability of Physical. Facilities for the Universal Basic Education Programme in Ekiti State, Nigeria. Middle-East Journal of Scientific Research 5 (1): 14-21.

Adeyemi, T.O (2009). Enrolment Analysis and Teacher Requirements for the Universal Basic Education Programme in Kwara State, Nigeria. Current Research Journal of Economic Theory 1(1):15-22.

Akinbote, O. (2001). The Nigerian Primary schoolteachers: Angels of instruction or devils of destruction? Nigerian Journal of Educational Philosophy, 4 (1) 35-40.

Akinbote, O. (2000). Problems of poor quality in primary school teacher preparation: A study of Nigeria's College of Education. African Journal of Educational Planning and Policy Studies, 1 (1) 33-39.

Aliyu A.I (2006.) Fundamental of General Principles and Practices of Education, Kano: our Saviour Publishers. Edem, E.C (2004). Educational Policies in Nigeria, Lagos: Marks press.

Aluede R.O.A (2006). Universal basic education in Nigeria: Matters arising. Journal of Human Ecology, 20(2): 97-101.

Arubayi E (2005). Comparing Average Distance Traveled to School by Students' in Primary and Secondary Schools in Delta and Edo State and its Effect on Attendance. DELSU Journal of Educational Research and Development, 4(1): 1-9.

Asiyai R.I (2012). Assessing School Facilities in Public Secondary Schools in Delta State, Nigeria. An International Multidisciplinary Journal, Ethiopia Vol. 6 (2), Serial No. 25.

Ayodele, J.B. (2004). The Role of Head teacher in School Plant Management and Maintenance.

In E.O. Fagbemiye, J.B. Babaloa et al (eds) Management of Primary and Secondary School Education in Nigeria. NAEAP publications.

Bassey, U.U., Ekpoh, U.I., \&Edet, A. O. (2008). Universal basic education as a vehicle for 
sustainable development: Reflections on implementation, problems and shortcomings in Akwa Ibom State, Nigeria. In J. B. Babalola, G.O. Akpa, I. Hauwa\&Ayeni, A. (Eds.). Managing education for sustainable development in developing countries. Lagos: NAEAP Publication.

Cheng, Y.C (1990). Conception of School Effectiveness and Models of School Evaluation: A Dynamic Perspective. Education Journal Vol. 18 No. 1, Page 47-61.

Chinelo O.U (2012). Educational policies/programmes' effect on attrition rates in primary schools in Nigeria. International Journal of Education Administration and Policy Studies Vol. 4(2), pp. 38-44.

Chux G.I and Ita C.I (2013). Factors Inhibiting Effective Management of Primary Schools in Nigeria: The Case of Ebonyi State., journal of social science 35(1): 51-60.

Denga D.I (2000). Evolving a New Educational Culture: The Universal Basic Education Focus. International Journal of Research in Basic and Life Long Education, 1(1\& 2) 1-6.

Ejima, E.D (2004). Correlate of Teacher Related Variables in the Implementation of School Curriculum. Journal of Special Education. 2(1) $34-48$.

Enamiroro P.O (2011). Implementation of the Primary School Curriculum Modules in Nigeria: The Role of Supervision. journal of Anthropologist, 13(2): 147-150.

National Population Commission (2006) 2006 Population and Housing census of the Federal republic of Nigeria, population and housing table, Kano state, march 2006 (vol. $1 \mathrm{~T}-\mathrm{D}-\mathrm{S}$ : 1. 19)

Research Advisor (2006), Population sampling size determination table Retrieved on October 25, $2020 \mathrm{from} \mathrm{http//researchadvisors.com}$

Sofowora O.A (2010). Improving the Standard and Quality of Primary Education in Nigeria: A Case Study of Oyo and Osun States., International Journal for Cross-Disciplinary Subjects in Education (IJCDSE), Volume 1, Issue 3. 